\title{
The multifaceted mechanism of Leptin signaling within tumor microenvironment in driving breast cancer growth and progression
}

\author{
Sebastiano Andò ${ }^{1}$, Ines Barone ${ }^{1}$, Cinzia Giordano ${ }^{2}$, Daniela Bonofiglio $^{1}$ and Stefania Catalano ${ }^{1}$ \\ Department of Pharmacy, Health and Nutritional Sciences, University of Calabria, Rende, Italy \\ ${ }^{2}$ Centro Sanitario, University of Calabria, Rende, Italy
}

Edited by:

Bianca Maria Veneziani, University of Naples Federico II, Italy

\section{Reviewed by:}

Deborah Stroka, University of Bern, Switzerland

Mary Helen Barcellos-Hoff, New York University School of Medicine, USA

\section{*Correspondence:}

Sebastiano Andò, Department of Pharmacy, Health and Nutritional Sciences, University of Calabria, Via P. Bucci, Arcavacata di Rende, Cosenza, 87036, Italy

e-mail:sebastiano.ando@unical.it
Adipokines represent likely candidates to mediate the increased breast cancer risk and the enhanced progression associated with obesity. Other contributors to obesity-related cancer progression are insulin/IGF-1 pathways and hormones. Among these, the adipokine leptin is the most intensively studied in both metabolism in general and in cancer due to the fact that leptin levels increase in proportion of fat mass. Leptin is primarily synthesized from adipocytes but it is also produced by other cells including fibroblasts. In this latter case, it has been well demonstrated how cancer-associated fibroblasts express leptin receptor and secrete leptin, which sustains a short autocrine loop and is able to target tumor epithelial cells enhancing breast cancer cell motility and invasiveness. In addition, it has been reported that leptin may induce breast cancer to undergo a transition from epithelial to spindle-like mesenchymal morphology, activating the signaling pathways devoted to the EMT. Thus, it emerges how leptin may play a crucial role in mediating malignant cell and tumor microenvironment interactions. Here, we present an overview of the role of leptin in breast cancer, covering the following topics: (1) leptin as an amplifier of estrogen signaling in tumor epithelial cells contributing to the promotion of carcinogenesis; (2) leptin as a crucial player in mediating tumor-stroma interaction and influencing EMT-linked mechanisms, that may sustain breast cancer growth and progression; (3) leptin and leptin receptor targeting as novel therapeutic strategies for breast cancer treatment.

Keywords: breast cancer, leptin-signaling pathway, estrogen receptor, tumor microenvironment, EMT, stem cells

\section{INTRODUCTION}

Breast cancer, a complex and heterogeneous disease, is one of the most common human malignancies in women worldwide. Breast cancer development and progression depend on both the accumulation of various genetic alterations in the epithelial cells of the mammary gland, and the reciprocal interaction between tumor cell itself and its surrounding microenvironment (stroma). The stroma of the breast is composed of the extracellular matrix components (ECM) as well as several cellular types such as endothelial cells, pericytes, immune and inflammatory cells, adipocytes, and fibroblasts [termed cancer-associated fibroblasts (CAFs)] (1). In breast tumors, $80 \%$ of CAFs are in active form (2), and secrete high levels of various growth factors, cytokines, chemokines, and ECM degrading proteases (3) that by different mechanisms promote breast tumor onset and progression. In this regard, we recently identified leptin as a main regulator in the crosstalk between breast cancer cells and CAFs, adding, for the first time, leptin to the list of growth factors able to mediate tumor-stromal interaction (4).

Leptin, whose synthesis and plasma levels increase proportionally to total adipose-tissue mass $(5,6)$, is a pleiotropic molecule that regulates food intake, inflammation, immunity, cell differentiation, and proliferation of different cell types including cells of the breast (7). The activities of leptin are mediated through the transmembrane leptin receptor (ObR) encoded by $\mathrm{db}$ gene, a member of the class I cytokine receptor family that includes six isoforms different in the length of their intracellular tails (8). Leptin binding to ObR induces activation of multiple intracellular signaling such as Janus kinase 2 -signal transducer and activator of transcription 3 (JAK2-STAT3), mitogen-activated protein kinase (MAPK), and phosphatidylinositol 3-kinase-protein kinase B (PI3K-AKT) pathways $(9,10)$ involved in different cellular activities. In the last decades, a plethora of data, strongly support the idea that leptin activity is correlated with breast cancer occurrence. Indeed, both leptin and its receptor are overexpressed in breast cancer, especially in higher grade tumors and are associated with distant metastasis $(11,12)$. Particularly, it has been extensively demonstrated using both in vitro and in vivo experimental models, that this adipokine modulates many aspects of breast cancer biology: e.g., increases cell proliferation and transformation, induces the expression of several cell cycle modulators, exerts anti-apoptotic effects, reduces efficacy of breast cancer treatment, influences cancer initiation processes (Table 1). Moreover, we and other authors have demonstrated that leptin can exert its activity also interacting with different signaling molecules.

In this review, we will focus on the role of leptin in breast cancer highlighting the following topics: (1) leptin as an amplifier of estrogen signaling in tumor epithelial cells contributing to the promotion of carcinogenesis; (2) leptin as a crucial player in 
Table 1 | Role of leptin in breast cancer growth and progression: in vitro and in vivo studies.

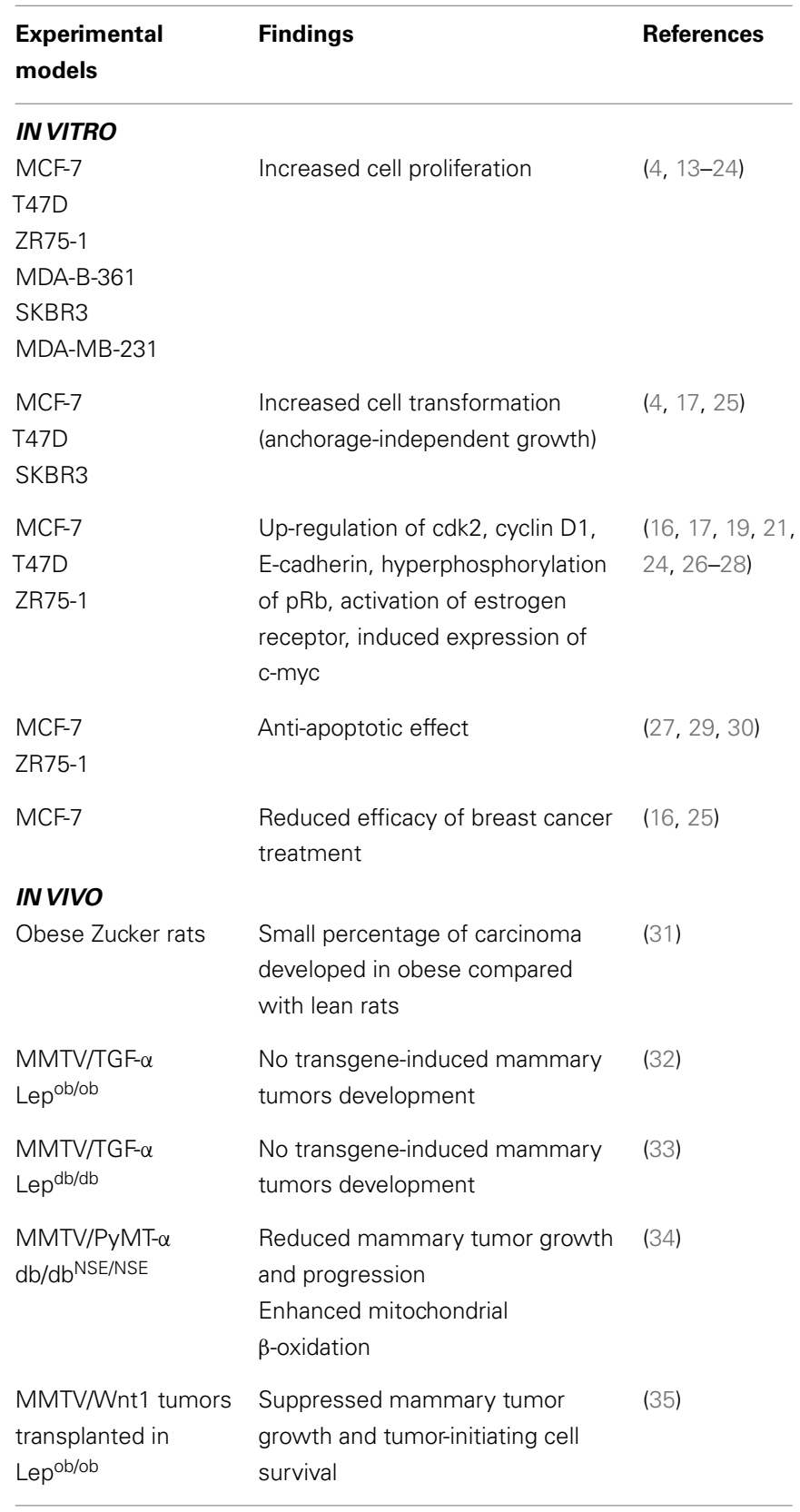

mediating tumor-stroma interaction and influencing EMT-linked mechanisms, that may sustain breast cancer growth and progression; (3) leptin and leptin receptor targeting as novel therapeutic strategies for breast cancer treatment.

\section{FUNCTIONAL CROSS-TALK BETWEEN LEPTIN AND ESTROGENS}

In addition to leptin, adipose tissue is a source of estrogens produced from androstenedione via aromatase conversion in postmenopausal women. Interestingly, several investigators have reported evidences that a functional cross-talk occurs between leptin and estrogen signaling network further contributes to breast carcinogenesis. Indeed, estrogen receptor (ER) $\alpha$ and ObRs are coexpressed in malignant mammary tissue and breast cancer cell lines $(15,17,18)$ and it has been shown a positive association between serum leptin levels and elevated values of estrogen and progesterone receptor in patients with breast cancer $(36,37)$. Similarly, in human primary breast cancers, leptin receptor expression is positively correlated with tumor size and ER expression (38). Moreover, it has been reported that estradiol administration increases leptin mRNA expression in adipose tissue (39) and induces an enhanced leptin and ObR expression in MCF-7 breast cancer cells (40).

On the other hand, leptin is a potent modulator of the estrogen signaling pathway. Specifically, we reported that leptin is able to activate $\mathrm{ER} \alpha$ transcriptionally through MAPK pathway in breast cancer cells in the absence of its natural ligand, reproducing the classic features of $\mathrm{ER} \alpha$ transactivation, such as nuclear localization, down-regulation of its mRNA and protein levels, and up-regulation of classic estrogen-dependent genes (26). Recently, we have also demonstrated that a lysine to arginine mutation at residue 303 (K303R) within the hinge domain of ER may potentiate ER $\alpha$ 's role as an effector of leptin intracellular signal transduction, which may enhance cell proliferation, migration and invasiveness, contributing to the more aggressive phenotype of K303R-associated breast cancers (4). Moreover, leptin-induced activation of ERK and STAT3 has been correlated with an increased expression of ER $\alpha$ in breast cancer cells (41) and in breast tumors of nude-mouse xenograft model (42). This evidence is also confirmed by analysis of 33 patients with breast cancer at different stages of disease, demonstrating a significant association between the expression of leptin receptor and ER $\alpha$ (41).

Leptin also interferes with the estrogen antagonists ICI 182,780 and tamoxifen used in the treatment of ER $\alpha$-positive tumors $(16,43)$.

Further evidence for the involvement of leptin in the paracrine stimulation of estrogen-responsive tissues is provided by its capacity to induce CYP19A1 synthesis in stromal cells isolated from the subcutaneous fat and breast adipose tissue of premenopausal women (44). In addition, Brown and colleagues have demonstrated that leptin stimulates aromatase expression in human breast adipose stromal cells through the regulation of LKB1/AMPK (AMP-activated protein kinase) pathway (45). Notably, they show that leptin downregulates LKB1 expression, accompanied by a decrease in AMPK phosphorylation, increased nuclear translocation of CRTC2 (CREB-regulated transcription coactivator 2), and a resulting increase in aromatase expression. Moreover, it has been reported that leptin enhances aromatase mRNA expression, protein content and its enzymatic activity in breast cancer cells, thereby promoting estradiol synthesis (13). This is mediated by AP1 (transcription activator protein 1) in ERK- and STAT3-dependent manner, since the presence of a MAPK inhibitor, ERK2- or STAT3-dominant negative constructs markedly attenuated the stimulatory effects of leptin on aromatase.

The enhanced local estrogen production induced by leptin could potentially also shape the breast cancer microenvironment. For example, local estrogens up-regulate TNF (tumor necrosis factor) receptor I expression in adipose-tissue fibroblast in an 
autocrine manner. Breast cancer epithelial cells produce large amounts of TNF, which through binding to TNF receptor I inhibits the differentiation of fibroblasts and preadipocytes into mature adipocytes, providing a molecular basis for the desmoplastic reaction commonly seen in breast cancer (46).

Overall, these studies indicate a biologically relevant cooperation between leptin and estrogen signaling pathways that might sustain the growth of estrogen-dependent breast cancer cells.

\section{MOLECULAR CONNECTION BETWEEN LEPTIN AND EMT}

In patients with breast cancer, metastasis rather than the primary tumor is the main cause of death. Epithelial-to-mesenchymal transition (EMT), a normal physiological process for embryonic development and wound healing, is thought to be involved in cancer progression and metastasis. Indeed, EMT represents a critical step in which a normal polarized epithelial cell undergoes several biochemical changes to acquire a mesenchymal cell phenotype, such as acquisition of migratory and invasive capabilities and the loss of cell-cell adhesion and cell polarity, resulting in tumor aggressiveness, recurrence, and overall poor prognosis. Recently, it has been found that CAFs and fibroblasts from breast reduction specimens are able to induce EMT in breast cancer cell lines (47-49). The role played by CAFs in the development and progression of breast cancer relies on their ability to produce stromal ECM (extracellular matrix) proteins and secrete many growth factors and hormones, including insulin like growth factor (IGF)-I, IGF-II, epidermal growth factor (EGF), transforming growth factor (TGF)- $\alpha$, TGF- $\beta$ (3). For instance, stromal fibroblasts isolated from invasive breast cancer tissues promote aggressive phenotypes of breast cancer cells through EMT induced by paracrine TGF- $\beta 1$ (50). Recently, we showed for the first time ObR RNA expression and leptin secretion in CAFs, proposing a novel integral role for leptin in mediating the bidirectional crosstalk between breast cancer cells and CAFs driving tumor growth and invasion (4). In parallel, it has been shown that leptin and its receptor initiate EMT via PI3K/Akt signaling pathway and $\beta$-catenin stabilization and nuclear translocation in breast cancer cells (51). The investigators observed in leptin-treated $\mathrm{ER} \alpha$-positive MCF-7 breast cancer cells as compared with untreated cells morphological phenotypic changes, including acquisition of fibroblast-like appearance, increased formation of pseudopodia from the cell membrane, reorganization of actin, and formation of stress fibers throughout cytoplasm. Such phenotypic differences were also reproduced upon leptin treatment in ER $\alpha$ negative MDA-MB-231 and in MDA-MB-468 breast cancer cells. Exposure of cells to leptin stimulation resulted in loss of expression of E-cadherin and up-regulation of mesenchymal markers, which include $\mathrm{N}$-cadherin, fibronectin, and vimentin. Expression of EMT inducers such as Snail, Slug, Zeb1, and Twist has also been found. The key mechanism underlying this important function of leptin involves a previously unrecognized interactions between leptin, metastasis-associated protein 1 (MTA1) and Wnt/ $\beta$-catenin pathways.

Over the last decade, it is emerged that EMT is involved in the generation and function of breast cancer stem cells (BCSCs), a population of highly tumorigenic cells characterized by the expression of molecular markers (phenotype CD $44^{+} \mathrm{CD} 24^{-} / \mathrm{ALDH}^{+}$) that, in favorable microenvironments, self-renew, proliferate, and can differentiate to cells that include the bulk of the tumor mass. These cells appear to promote angiogenesis and escape immune surveillance, and chemo- and radio-therapy (52). Leptin has been reported to regulate and activate several signaling pathways and oncogenes, such as HER2, and AKT as well as transcription factors, such as STAT3 and NF- $\mathrm{B}$, which are critically implicated in BCSCs $(53,54)$. In addition, leptin also activates the Notch signaling pathway $(55,56)$ that is an important stem-cell signaling network. Interestingly, it has been found that leptin induces the expression of CD44 and ALDH1 in several cancer cell lines (53). Zheng et al. have reported a decreased tumor outgrowth and a functional depletion of BCSCs in obese leptin-deficient mice transplanted with murine mammary tumor virus (MMTV)-Wnt1 tumor cells, showing that leptin signaling has an important role in tumor cell growth and stem-cell survival (35). Another study has also demonstrated that expression of $\mathrm{Ob}-\mathrm{R}$ is a characteristic feature of CSCs, that display sensitized responses to leptin, such as STAT3 phosphorylation and activation along with Oct4 and Sox2 overexpression, thereby creating a self-reinforcing signaling network (57). More recently, it has been shown that the leptin receptor is necessary for maintaining CSC-like and metastatic properties in triple-negative breast cancer cells (58).

Given all the potential roles of leptin in the multistep processes of breast cancer progression, involving tumor initiation, primary tumor growth, invasion and metastasis, the leptin-signaling network is emerging as a novel therapeutic target for patients with breast cancers.

\section{LEPTIN AS A POTENTIAL TARGET OF THE NOVEL THERAPEUTIC STRATEGIES FOR BREAST CANCER TREATMENT}

Several therapeutic approaches that could interfere with the actions of leptin and thereby prevent or delay leptin-related disease have been proposed (59).

\section{SOLUBLE LEPTIN RECEPTORS}

Recombinant leptin-binding domains have been indicated as a treatment to block free leptin but they do not completely neutralize leptin activity due to a lower affinity for leptin compared to the intact soluble leptin receptor. $(60,61)$. However, several investigators have synthesized receptor-binding fragments able to inhibit leptin-induced proliferation and oncogenic signaling in both ER-positive and -negative breast cancer cells (62-64).

\section{PEPTIDE-BASED LEPTIN ANTAGONISTS}

An altered form of human leptin containing the mutation Arg128Gln was the first leptin antagonist synthesized. This mutation, tested in BAF/3 cells (an immortalized murine bone marrowderived pro-B-cell line) stably transfected with the long form of human leptin receptor, exhibited binding properties similar to wild-type leptin, although it demonstrated reduced biological activity and weak antagonist properties when tested in cell proliferation assays (65). Another study has demonstrated that high doses of a short peptide sequences corresponding to amino acids 70-95 of human leptin is able to reverse leptin activity in vitro and in vivo (66-68). Moreover, Gertler et al. have demonstrated that mutations in sequence 39-42 (LDFI) of leptin lead to leptin 


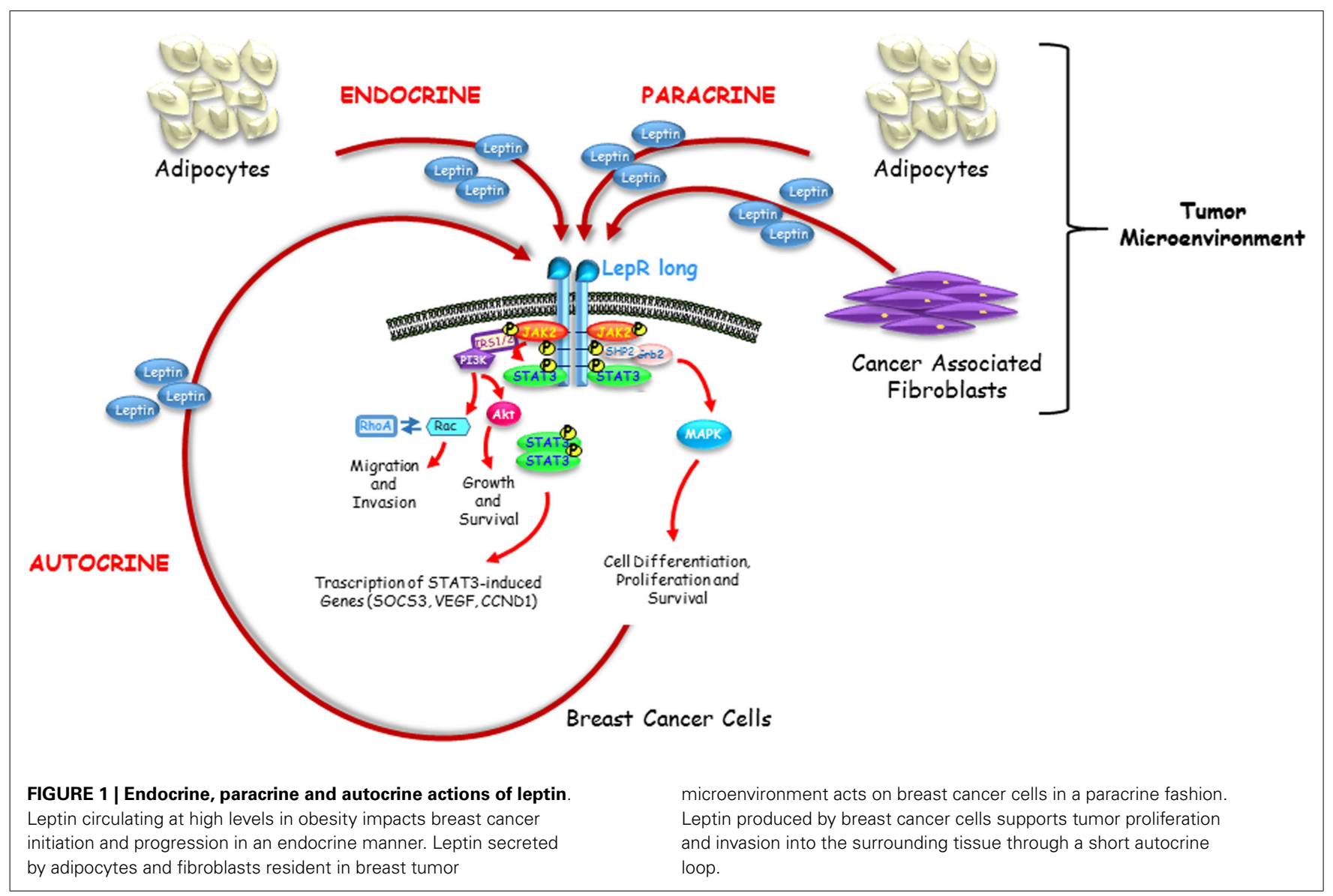

muteins that still bind the receptor, but do not activate it $(69,70)$. Conversion of these amino acids to alanine resulted in the creation of leptin antagonists, being able to block endogenous leptin action in intact animals. Subsequent studies have (71-73) discovered another residue, Asp23, whose mutagenesis is associated with a dramatic increase in leptin-binding affinity. The simultaneous mutation of Asp23 with leucine and LDF with alanine, made it possible to synthesize the mutein D23L/L39A/D40A/F41A having a binding affinity receptor 60 times greater and antagonistic activity 14 times greater, in vitro, compared to the simple mutation LDF. Recently, we have synthesized a small peptide based on the wild-type sequence of leptin-binding site I, and demonstrated its efficacy in antagonizing leptin activity in breast cancer cell lines and in in vivo experimental models (data not published).

\section{LEPTIN-RECEPTOR-BLOCKING ANTIBODIES}

Leptin binding and signaling could be prevented by using highaffinity monoclonal antibodies that act as antagonists by interacting with the leptin receptor (74-76). A leptin-receptor-specific antibody has been tested in an in vitro study, and resulted in a reduction of both leptin signaling and leptin's capability to activate monocytes and induce proliferation of peripheral blood mononuclear cells (75). The use of polyclonal antibodies that block leptin has also been proposed $(74,76)$. However, such antibodies could increase, rather than block, the activity of leptin in vivo, by prolonging its half-life in the circulation. The leptinantibody complex would be larger than leptin alone, thereby decreasing kidney-mediated clearance of leptin (71). An alternative approach is represented by single-domain antibodies, i.e., small, monomeric antibody fragments of around $15 \mathrm{kDa}$ that contain a single antigen-binding domain. These fragments are able to target the leptin receptor and block the ligand-induced conformational switch without interfering with leptin-leptin receptor interactions. They can bind to the leptin receptor with high affinity and do not cross the blood-brain barrier; thereby, they could selectively inhibit the peripheral activity of leptin (71).

\section{CONCLUSION}

Adipokine leptin, produced by adipocytes, fibroblasts, and breast cancer cells, may act in an endocrine, paracrine as well as autocrine manner on breast cancer tissue (Figure 1). Activation of leptinsignaling results in concurrent activation of multiple oncogenic pathways leading to increased proliferation, acquisition of mesenchymal phenotype, enhanced migration, and invasion of tumor cells. Knowledge of the complex biological molecular network of leptin-signaling responsible for mammary carcinogenesis within tumor microenvironment provides a strong rationale for developing new agents, tailored to target the leptin and its receptor pathways, for therapeutic intervention in breast cancer treatment, particularly in women with obesity.

\section{ACKNOWLEDGMENTS}

This work was supported by Associazione Italiana Ricerca sul Cancro (AIRC) grant IG11595. 


\section{REFERENCES}

1. Arendt LM, Rudnick JA, Keller PJ, Kuperwasser C. Stroma in breast development and disease. Semin Cell Dev Biol (2009) 21:11-8. doi:10.1016/j.semcdb. 2009.10.003

2. Aboussekhra A. Role of cancer-associated fibroblasts in breast cancer development and prognosis. Int J Dev Biol (2011) 55:841-9. doi:10.1387/ijdb.113362aa

3. Bhowmick NA, Neilson EG, Moses HL. Stromal fibroblasts in cancer initiation and progression. Nature (2004) 432:332-7. doi:10.1038/nature03096

4. Barone I, Catalano S, Gelsomino L, Marsico S, Giordano C, Panza S. Leptin mediates tumor-stromal interactions that promote the invasive growth of breast cancer cells. Cancer Res (2012) 72:1416-27. doi:10.1158/0008-5472.CAN11-2558

5. Considine RV, Sinha MK, Heiman ML, Kriauciunas A, Stephens TW, Nyce MR. Serum immunoreactive-leptin concentrations in normal-weight and obese humans. N Engl J Med (1996) 334:292-5. doi:10.1056/NEJM199602013340503

6. Maffei M, Halaas J, Ravussin E, Pratley RE, Lee GH, Zhang Y. Leptin levels in human and rodent: measurement of plasma leptin and ob RNA in obese and weight-reduced subjects. Nat Med (1995) 1:1155-61. doi:10.1038/nm1195- 1155

7. Andò S, Catalano S. The multifactorial role of leptin in driving the breast cancer microenvironment. Nat Rev Endocrinol (2011) 8:263-75. doi:10.1038/nrendo. 2011.184

8. Cirillo D, Rachiglio AM, la Montagna R, Giordano A, Normanno N. Leptin signaling in breast cancer: an overview. J Cell Biochem (2008) 105:956-64. doi:10.1002/jcb.21911

9. Ahima RS, Osei SY. Leptin signaling. Physiol Behav (2004) 81:223-41. doi:10. 1016/j.physbeh.2004.02.014

10. Sweeney G. Leptin signalling. Cell Signal (2002) 14:655-63. doi:10.1016/S08986568(02)00006-2

11. Ishikawa M, Kitayama J, Nagawa H. Enhanced expression of leptin and leptin receptor (OB-R) in human breast cancer. Clin Cancer Res (2004) 10:4325-31. doi:10.1158/1078-0432.CCR-03-0749

12. Miyoshi Y, Funahashi T, Tanaka S, Taguchi T, Tamaki Y, Shimomura I. High expression of leptin receptor mRNA in breast cancer tissue predicts poor prognosis for patients with high, but not low, serum leptin levels. Int J Cancer (2006) 118:1414-9. doi:10.1002/ijc.21543

13. Catalano S, Marsico S, Giordano C, Mauro L, Rizza P, Panno ML. Leptin enhances, via AP-1, expression of aromatase in the MCF-7 cell line. J Biol Chem (2003) 278:28668-76. doi:10.1074/jbc.M301695200

14. Catalano S, Mauro L, Bonofiglio D, Pellegrino M, Qi H, Rizza P. In vivo and in vitro evidence that PPARgamma ligands are antagonists of leptin signaling in breast cancer. Am J Pathol (2011) 179:1030-40. doi:10.1016/j.ajpath.2011.04.026

15. Dieudonne MN, Machinal-Quelin F, Serazin-Leroy V, Leneveu MC, Pecquery R, Giudicelli Y. Leptin mediates a proliferative response in human MCF7 breast cancer cells. Biochem Biophys Res Commun (2002) 293:622-8. doi:10.1016/ S0006-291X(02)00205-X

16. Garofalo C, Sisci D, Surmacz E. Leptin interferes with the effects of the antiestrogen ICI 182,780 in MCF-7 breast cancer cells. Clin Cancer Res (2004) 10:6466-75. doi:10.1158/1078-0432.CCR-04-0203

17. Hu X, Juneja SC, Maihle NJ, Cleary MP. Leptin - a growth factor in normal and malignant breast cells and for normal mammary gland development. J Natl Cancer Inst (2002) 94:1704-11. doi:10.1093/jnci/94.22.1704

18. Laud K, Gourdou I, Pessemesse L, Peyrat JP, Djiane J. Identification of leptin receptors in human breast cancer: functional activity in the T47-D breast cancer cell line. Mol Cell Endocrinol (2002) 188:219-26. doi:10.1016/S0303-7207(01) 00678-5

19. Okumura M, Yamamoto M, Sakuma H, Kojima T, Maruyama T, Jamali M. Leptin and high glucose stimulate cell proliferation in MCF-7 human breast cancer cells: reciprocal involvement of PKC-alpha and PPAR expression. Biochim Biophys Acta (2002) 1592:107-16. doi:10.1016/S0167-4889(02)00276-8

20. Ray A, Nkhata KJ, Cleary MP. Effects of leptin on human breast cancer cell lines in relationship to estrogen receptor and HER2 status. Int J Oncol (2007) 30:1499-509. doi:10.3892/ijo.30.6.1499

21. Saxena NK, Vertino PM, Anania FA, Sharma D. Leptin-induced growth stimulation of breast cancer cells involves recruitment of histone acetyltransferases and mediator complex to CYCLIN D1 promoter via activation of Stat3. J Biol Chem (2007) 282:13316-25. doi:10.1074/jbc.M609798200

22. Soma D, Kitayama J, Yamashita H, Miyato H, Ishikawa M, Nagawa H. Leptin augments proliferation of breast cancer cells via transactivation of HER2. J Surg Res (2008) 149:9-14. doi:10.1016/j.jss.2007.10.012
23. Somasundar P, Yu AK, Vona-Davis L, McFadden DW. Differential effects of leptin on cancer in vitro. J Surg Res (2003) 113:50-5. doi:10.1016/S0022-4804(03) 00166-5

24. Yin N, Wang D, Zhang H, Yi X, Sun X, Shi B. Molecular mechanisms involved in the growth stimulation of breast cancer cells by leptin. Cancer Res (2004) 64:5870-5. doi:10.1158/0008-5472.CAN-04-0655

25. Giordano C, Vizza D, Panza S, Barone I, Bonofiglio D, Lanzino M. Leptin increases HER2 protein levels through a STAT3-mediated up-regulation of Hsp90 in breast cancer cells. Mol Oncol (2013) 7:379-91. doi:10.1016/j.molonc. 2012.11.002

26. Catalano S, Mauro L, Marsico S, Giordano C, Rizza P, Rago V. Leptin induces, via ERK1/ERK2 signal, functional activation of estrogen receptor alpha in MCF-7 cells. J Biol Chem (2004) 279:19908-15. doi:10.1074/jbc.M313191200

27. Chen ZL, Wang DM, Duan JF, Wen SQ, Tang YF, Li ZX. Leptin enhances the release of cytokines by peripheral blood mononuclear cells from acute multiple sclerosis patients. Neurosci Bull (2006) 22:115-7.

28. Mauro L, Catalano S, Bossi G, Pellegrino M, Barone I, Morales S. Evidences that leptin up-regulates E-cadherin expression in breast cancer: effects on tumor growth and progression. Cancer Res (2007) 67:3412-21. doi:10.1158/0008-5472. CAN-06-2890

29. Jiang H, Yu J, Guo H, Song H, Chen S. Upregulation of survivin by leptin/STAT3 signaling in MCF-7 cells. Biochem Biophys Res Commun (2008) 368:1-5. doi:10.1016/j.bbrc.2007.04.004

30. Perera CN, Chin HG, Duru N, Camarillo IG. Leptin-regulated gene expression in MCF-7 breast cancer cells: mechanistic insights into leptin-regulated mammary tumor growth and progression. J Endocrinol (2008) 199:221-33. doi:10.1677/JOE-08-0215

31. Lee WM, Lu S, Medline A, Archer MC. Susceptibility of lean and obese Zucker rats to tumorigenesis induced by N-methyl-N-nitrosourea. Cancer Lett (2001) 162:155-60. doi:10.1016/S0304-3835(00)00635-2

32. Cleary MP, Phillips FC, Getzin SC, Jacobson TL, Jacobson MK, Christensen TA. Genetically obese MMTV-TGF-alpha/Lep(ob)Lep(ob) female mice do not develop mammary tumors. Breast Cancer Res Treat (2003) 77:205-15. doi:10.1023/A:1021891825399

33. Cleary MP, Juneja SC, Phillips FC, Hu X, Grande JP, Maihle NJ. Leptin receptor-deficient MMTV-TGF-alpha/Lepr $(\mathrm{db}) \operatorname{Lepr}(\mathrm{db})$ female mice do not develop oncogene-induced mammary tumors. Exp Biol Med (Maywood) (2004) 229:182-93.

34. Park J, Kusminski CM, Chua SC, Scherer PE. Leptin receptor signaling supports cancer cell metabolism through suppression of mitochondrial respiration in vivo. Am J Pathol (2010) 177:3133-44. doi:10.2353/ajpath.2010.100595

35. Zheng Q, Dunlap SM, Zhu J, Downs-Kelly E, Rich J, Hursting SD. Leptin deficiency suppresses MMTV-Wnt-1 mammary tumor growth in obese mice and abrogates tumor initiating cell survival. Endocr Relat Cancer (2011) 18:491-503. doi:10.1530/ERC-11-0102

36. Tessitore L, Vizio B, Jenkins O, De Stefano I, Ritossa C, Argiles JM. Leptin expression in colorectal and breast cancer patients. Int J Mol Med (2000) 5:421-6. doi:10.3892/ijmm.5.4.421

37. Tessitore L, Vizio B, Pesola D, Cecchini F, Mussa A, Argiles JM. Adipocyte expression and circulating levels of leptin increase in both gynaecological and breast cancer patients. Int J Oncol (2004) 24:1529-35. doi:10.3892/ijo.24.6.1529

38. Jarde T, Caldefie-Chezet F, Damez M, Mishellany F, Penault-Llorca F, Guillot J. Leptin and leptin receptor involvement in cancer development: a study on human primary breast carcinoma. Oncol Rep (2008) 19:905-11. doi:10.3892/or. 19.4.905

39. Machinal-Quelin F, Dieudonne MN, Pecquery R, Leneveu MC, Giudicelli Y. Direct in vitro effects of androgens and estrogens on ob gene expression and leptin secretion in human adipose tissue. Endocrine (2002) 18:179-84. doi:10.1385/ENDO:18:2:179

40. Garofalo C, Koda M, Cascio S, Sulkowska M, Kanczuga-Koda L, Golaszewska J. Increased expression of leptin and the leptin receptor as a marker of breast cancer progression: possible role of obesity-related stimuli. Clin Cancer Res (2006) 12:1447-53. doi:10.1158/1078-0432.CCR-05-1913

41. Fusco R, Galgani M, Procaccini C, Franco R, Pirozzi G, Fucci L. Cellular and molecular crosstalk between leptin receptor and estrogen receptor-\{alpha\} in breast cancer: molecular basis for a novel therapeutic setting. Endocr Relat Cancer (2010) 17:373-82. doi:10.1677/ERC-09-0340

42. Yu W, Gu JC, Liu JZ, Wang SH, Wang Y, Zhang ZT. Regulation of estrogen receptors alpha and beta in human breast carcinoma by exogenous leptin 
in nude mouse xenograft model. Chin Med J (Engl) (2010) 123:337-43. doi:10.3760/cma.j.issn.0366-6999.2010.03.015

43. Yom CK, Lee KM, Han W, Kim SW, Kim HS, Moon BI. Leptin as a potential target for estrogen receptor-positive breast cancer. J Breast Cancer (2013) 16:138-45. doi:10.4048/jbc.2013.16.2.138

44. Magoffin DA, Weitsman SR, Aagarwal SK, Jakimiuk AJ. Leptin regulation of aromatase activity in adipose stromal cells from regularly cycling women. Ginekol Pol (1999) 70:1-7.

45. Brown KA, McInnes KJ, Hunger NI, Oakhill JS, Steinberg GR, Simpson ER. Subcellular localization of cyclic AMP-responsive element binding proteinregulated transcription coactivator 2 provides a link between obesity and breast cancer in postmenopausal women. Cancer Res (2009) 69:5392-9. doi:10.1158/ 0008-5472.CAN-09-0108

46. Schaffler A, Scholmerich J, Buechler C. Mechanisms of disease: adipokines and breast cancer - endocrine and paracrine mechanisms that connect adiposity and breast cancer. Nat Clin Pract Endocrinol Metab (2007) 3:345-54. doi:10.1038/ncpendmet0456

47. De Wever O, Mareel M. Role of tissue stroma in cancer cell invasion. J Pathol (2003) 200:429-47. doi:10.1002/path.1398

48. Gao MQ, Kim BG, Kang S, Choi YP, Park H, Kang KS. Stromal fibroblasts from the interface zone of human breast carcinomas induce an epithelialmesenchymal transition-like state in breast cancer cells in vitro. J Cell Sci (2010) 123:3507-14. doi:10.1242/jcs.072900

49. Lebret SC, Newgreen DF, Thompson EW, Ackland ML. Induction of epithelial to mesenchymal transition in PMC42-LA human breast carcinoma cells by carcinoma-associated fibroblast secreted factors. Breast Cancer Res (2007) 9:R19. doi:10.1186/bcr1656

50. Yu Y, Xiao CH, Tan LD, Wang QS, Li XQ, Feng YM. Cancer-associated fibroblasts induce epithelial-mesenchymal transition of breast cancer cells through paracrine TGF-beta signalling. Br J Cancer (2014) 110:724-32. doi:10.1038/bjc. 2013.768

51. Yan D, Avtanski D, Saxena NK, Sharma D. Leptin-induced epithelialmesenchymal transition in breast cancer cells requires beta-catenin activation via Akt/GSK3- and MTA1/Wnt1 protein-dependent pathways. J Biol Chem (2012) 287:8598-612. doi:10.1074/jbc.M111.322800

52. Mallini P, Lennard T, Kirby J, Meeson A. Epithelial-to-mesenchymal transition: what is the impact on breast cancer stem cells and drug resistance. Cancer Treat $\operatorname{Rev}(2014)$ 40:341-8. doi:10.1016/j.ctrv.2013.09.008

53. Guo S, Liu M, Wang G, Torroella-Kouri M, Gonzalez-Perez RR. Oncogenic role and therapeutic target of leptin signaling in breast cancer and cancer stem cells. Biochim Biophys Acta (2012) 1825:207-22. doi:10.1016/j.bbcan.2012.01. 002

54. Saxena NK, Sharma D. Multifaceted leptin network: the molecular connection between obesity and breast cancer. J Mammary Gland Biol Neoplasia (2013) 18:309-20. doi:10.1007/s10911-013-9308-2

55. Guo S, Gonzalez-Perez RR. Notch, IL-1 and leptin crosstalk outcome (NILCO) is critical for leptin-induced proliferation, migration and VEGF/VEGFR-2 expression in breast cancer. PLoS One (2011) 6:e21467. doi:10.1371/journal.pone. 0021467

56. Knight BB, Oprea-Ilies GM, Nagalingam A, Yang L, Cohen C, Saxena NK. Survivin upregulation, dependent on leptin-EGFR-Notch1 axis, is essential for leptin-induced migration of breast carcinoma cells. Endocr Relat Cancer (2011) 18:413-28. doi:10.1530/ERC-11-0075

57. Feldman DE, Chen C, Punj V, Tsukamoto H, Machida K. Pluripotency factormediated expression of the leptin receptor (OB-R) links obesity to oncogenesis through tumor-initiating stem cells. Proc Natl Acad Sci U S A (2012) 109:829-34. doi:10.1073/pnas.1114438109

58. Zheng Q, Banaszak L, Fracci S, Basali D, Dunlap SM, Hursting SD. Leptin receptor maintains cancer stem-like properties in triple negative breast cancer cells. Endocr Relat Cancer (2013) 20:797-808. doi:10.1530/ERC-13-0329

59. Leggio A, Catalano S, De Marco R, Barone I, Ando S, Liguori A. Therapeutic potential of leptin receptor modulators. Eur J Med Chem (2014) 78:97-105. doi:10.1016/j.ejmech.2014.03.048

60. Niv-Spector L, Gonen-Berger D, Gourdou I, Biener E, Gussakovsky EE, Benomar Y. Identification of the hydrophobic strand in the A-B loop of leptin as major binding site III: implications for large-scale preparation of potent recombinant human and ovine leptin antagonists. Biochem J (2005) 391:221-30. doi:10.1042/BJ20050457

61. Sandowski Y, Raver N, Gussakovsky EE, Shochat S, Dym O, Livnah O. Subcloning, expression, purification, and characterization of recombinant human leptin-binding domain. J Biol Chem (2002) 277:46304-9. doi:10.1074/jbc. M207556200

62. Otvos L Jr, Terrasi M, Cascio S, Cassone M, Abbadessa G, De Pascali F. Development of a pharmacologically improved peptide agonist of the leptin receptor. Biochim Biophys Acta (2008) 1783:1745-54. doi:10.1016/j.bbamcr.2008.05.007

63. Otvos L Jr, Kovalszky I, Riolfi M, Ferla R, Olah J, Sztodola A. Efficacy of a leptin receptor antagonist peptide in a mouse model of triple-negative breast cancer. Eur J Cancer (2011) 47:1578-84. doi:10.1016/j.ejca.2011.01.018

64. Otvos L Jr, Kovalszky I, Scolaro L, Sztodola A, Olah J, Cassone M. Peptidebased leptin receptor antagonists for cancer treatment and appetite regulation. Biopolymers (2011) 96:117-25. doi:10.1002/bip.21377

65. Raver N, Vardy E, Livnah O, Devos R, Gertler A. Comparison of R128Q mutations in human, ovine, and chicken leptins. Gen Comp Endocrinol (2002) 126:52-8. doi:10.1006/gcen.2001.7766

66. Battle M, Gillespie C, Quarshie A, Lanier V, Harmon T, Wilson K. Obesity induced a leptin-Notch signaling axis in breast cancer. Int J Cancer (2014) 134:1605-16. doi:10.1002/ijc.28496

67. Gonzalez RR, Leavis PC. A peptide derived from the human leptin molecule is a potent inhibitor of the leptin receptor function in rabbit endometrial cells. Endocrine (2003) 21:185-95. doi:10.1385/ENDO:21:2:185

68. Rene Gonzalez R, Watters A, Xu Y, Singh UP, Mann DR, Rueda BR. Leptinsignaling inhibition results in efficient anti-tumor activity in estrogen receptor positive or negative breast cancer. Breast Cancer Res (2009) 11:R36. doi:10.1186/bcr2321

69. Niv-Spector L, Raver N, Friedman-Einat M, Grosclaude J, Gussakovsky EE, Livnah O. Mapping leptin-interacting sites in recombinant leptin-binding domain (LBD) subcloned from chicken leptin receptor. Biochem J (2005) 390:475-84. doi:10.1042/BJ20050233

70. Salomon G, Niv-Spector L, Gussakovsky EE, Gertler A. Large-scale preparation of biologically active mouse and rat leptins and their L39A/D40A/F41A muteins which act as potent antagonists. Protein Expr Purif (2006) 47:128-36. doi:10.1016/j.pep.2005.09.016

71. Gertler A. Development of leptin antagonists and their potential use in experimental biology and medicine. Trends Endocrinol Metab (2006) 17:372-8. doi:10.1016/j.tem.2006.09.006

72. Niv-Spector L, Shpilman M, Boisclair Y, Gertler A. Large-scale preparation and characterization of non-pegylated and pegylated superactive ovine leptin antagonist. Protein Expr Purif (2012) 81:186-92. doi:10.1016/j.pep.2011.10.003

73. Shpilman M, Niv-Spector L, Katz M, Varol C, Solomon G, Ayalon-Soffer M. Development and characterization of high affinity leptins and leptin antagonists. J Biol Chem (2011) 286:4429-42. doi:10.1074/jbc.M110.196402

74. De Rosa V, Procaccini C, La Cava A, Chieffi P, Nicoletti GF, Fontana S. Leptin neutralization interferes with pathogenic $\mathrm{T}$ cell autoreactivity in autoimmune encephalomyelitis. J Clin Invest (2006) 116:447-55. doi:10.1172/JCI26523

75. Fazeli M, Zarkesh-Esfahani H, Wu Z, Maamra M, Bidlingmaier M, Pockley AG. Identification of a monoclonal antibody against the leptin receptor that acts as an antagonist and blocks human monocyte and T cell activation. J Immunol Methods (2006) 312:190-200. doi:10.1016/j.jim.2006.03.011

76. Matarese G, Carrieri PB, La Cava A, Perna F, Sanna V, De Rosa V. Leptin increase in multiple sclerosis associates with reduced number of $\mathrm{CD} 4(+) \mathrm{CD} 25+$ regulatory T cells. Proc Natl Acad Sci U S A (2005) 102:5150-5. doi:10.1073/pnas. 0408995102

Conflict of Interest Statement: The authors declare that the research was conducted in the absence of any commercial or financial relationships that could be construed as a potential conflict of interest.

Received: 23 September 2014; paper pending published: 27 October 2014; accepted: 12 November 2014; published online: 26 November 2014.

Citation: Andò S, Barone I, Giordano C, Bonofiglio D and Catalano S (2014) The multifaceted mechanism of Leptin signaling within tumor microenvironment in driving breast cancer growth and progression. Front. Oncol. 4:340. doi: 10.3389/fonc. 2014.00340

This article was submitted to Molecular and Cellular Oncology, a section of the journal Frontiers in Oncology.

Copyright $\odot 2014$ Andò, Barone, Giordano, Bonofiglio and Catalano. This is an openaccess article distributed under the terms of the Creative Commons Attribution License (CC BY). The use, distribution or reproduction in other forums is permitted, provided the original author(s) or licensor are credited and that the original publication in this journal is cited, in accordance with accepted academic practice. No use, distribution or reproduction is permitted which does not comply with these terms. 